\title{
Artikel
}

\section{Opteren voor de Netherlands Commercial Court}

\author{
J. Hoeben LLM, prof. mr. A.L.M. Keirse en M.D. Reijneveld LLB*
}

\section{Inleiding}

Contracteren leidt meer dan eens tot handelsgeschillen en doordat dit meer en meer grensoverschrijdend geschiedt, worden deze handelsgeschillen internationaler. Bij internationale handelsgeschillen wijzen in eerste instantie regels van internationaal privaatrecht de weg. Volgens deze regels kunnen contractspartijen bijvoorbeeld op verschillende momenten vastleggen welk forum zij benaderen indien zich een geschil voordoet. ${ }^{1}$ Dit kan in de eerste plaats worden vastgelegd op het moment dat partijen met elkaar in onderhandeling treden in het tussen hen geldende contract door middel van een forumkeuzebeding. In de tweede plaats kan dit ook eerst tussen partijen worden overeengekomen nadat een geschil is ontstaan aan de hand van een forumkeuzeovereenkomst. Daarbij kunnen partijen verschillende fora kiezen om geschillen aan voor te leggen, nationaal of internationaal. Zij kunnen allereerst voor nationale arbitrage of een nationaal gerecht kiezen, maar daarnaast ook voor internationale arbitrage of een meer internationaal opererende overheidsrechter, een commercial court. Bij arbitrage kunnen partijen afspraken maken over de taal waarin de procedure wordt gevoerd en over de arbi-

* J. Hoeben LLM is student aan de Universiteit Utrecht, Legal Research Master. Prof. mr. A.L.M. Keirse is als hoogleraar Privaatrecht verbonden aan het Utrecht Centre for Accountability and Liability Law (UCALL) en het Molengraaff Instituut voor Privaatrecht van de Universiteit Utrecht. Zij is daarnaast (parttime) raadsheer bij het Gerechtshof Amsterdam. M.D. Reijneveld LLB is student aan de Universiteit Utrecht, Legal Research Master.

1. Zie o.a. art. 25 Brussel I-Verordening herschikking en voor de keuze voor de Nederlandse rechter art. 8 Rv. trale regels die van toepassing zijn. Nederlandse contractspartijen kiezen er bijvoorbeeld voor om hun (internationale) geschillen voor te leggen aan het Nederlands Arbitrage Instituut, de Raad van Arbitrage voor de Bouw, het International Court of Arbitration van de International Chamber of Commerce in Parijs, de London Court of International Arbitration of aan een arbitragetribunaal dat is opgericht onder auspiciën van het Permanent Hof van Arbitrage. Daarnaast kan de keuze vallen op gerechten die zich specifiek richten op complexe internationale handelsgeschillen, oftewel commercial courts. Belangrijke commercial courts liggen in Londen en Singapore, maar daarnaast zijn er ook commercial courts in Dublin, Delaware en Dubai. ${ }^{2}$ In toenemende mate worden internationale handelsgeschillen beslecht door middel van (internationale) arbitrage of door buitenlandse overheidsrechters. ${ }^{3}$

Thans wordt ook in Nederland een commercial court opgericht: de Netherlands Commercial Court (NCC). In dit artikel verkennen wij welke positieve mogelijkheden de NCC kan bieden voor de Nederlandse rechtspraktijk, en wat de Nederlandse rechtspraktijk kan doen om bij te dragen aan het succes van de NCC.

Ten behoeve van deze verkenning wordt de NCC voor het voetlicht gebracht. $\mathrm{Na}$ een korte inleiding op het ontstaan van de NCC in paragraaf 2.1, gaan wij in paragraaf 2.2 in op de verschillende aspecten van de NCC. Kort samengevat is de NCC een nieuw forum voor geschillenbeslechting dat de mogelijkheid biedt om vrijwillig internationale handelsgeschillen in de Engelse taal voor te leggen aan een meervoudige kamer van de NCC, en in hoger beroep aan de Netherlands Commercial Court

2. Raad voor de rechtspraak, Plan tot oprichting van de Netherlands Commercial Court. Inclusief kosten-batenanalyse, 2015, p. 4.

3. Raad voor de rechtspraak 2015, p. 5. 
of Appeal (NCCA), die op snelle en efficiënte wijze zullen werken en kostenneutraal zijn. Deze verschillende kenmerken van de NCC worden afzonderlijk besproken. Vervolgens beantwoorden wij in paragraaf 3 de vraag welke mogelijkheden en voordelen de NCC kan bieden voor de Nederlandse rechtspraktijk. Wij trekken hier een vergelijking met andere commercial courts, met name die in Londen. Daarna besteden wij kort aandacht aan de vraag wat de sleutel tot succes voor de NCC zou kunnen zijn. Daarbij ligt de focus op aspecten waaraan de Nederlandse rechtspraktijk actief kan bijdragen. Wij sluiten af met een kort besluit in paragraaf 5 , waarin de geschetste hoofdlijnen samenkomen.

\section{Introductie van de NCC}

\subsection{De plannen gedoopt}

De oprichting van de NCC vergt een goede voorbereiding. De ambitie om de NCC op te richten is aan het einde van de zomer van 2014 uitgesproken door de voorzitter van de Raad voor de rechtspraak. ${ }^{4}$ Een voorbereidingsproces met uitgebreid onderzoek volgde. Onderzocht is of er in het Nederlandse bedriifsleven behoefte bestaat an een dergelijke speciale instantie die grote internationale handelsgeschillen behandelt, en of het mogelijk zou zijn om zo'n voorziening in Nederland te verwezenlijken. ${ }^{5}$ Daarnaast is verkennend onderzoek gestart naar het aantal en het soort zaken dat bij een de kerst van 2016 gepubliceerd..$^{9}$ Door invoeging van een nieuw artikel 30r in het Wetboek van Burgerlijke Rechtsvordering (Rv) wordt het mogelijk gemaakt dat door een Nederlands gerecht in het Engels uitspraak wordt gedaan. De vaststelling van het daarbij te hanteren hogere griffierecht wordt neergelegd in een in te voeren artikel 9a van de Wet griffierechten burgerlijke zaken. $\mathrm{Na}$ het akkoord van de ministerraad afgelopen februari is sinds maart een adviesaanvraag bij de Raad van State aanhangig over het desbetreffende wetsvoorstel. ${ }^{10}$ De geplande startdatum van 1 januari 2017 is weliswaar uitgesteld, maar niettemin is het nog immer het plan dat de NCC in 2017 van start zal gaan. ${ }^{11}$

Hoewel 2017 - tegen de tijd dat dit nummer van Contracteren verschijnt - al ver op weg is en het wetsvoorstel dan mogelijk al bij de Tweede Kamer ligt, is nog niet bij alle lezers bekend dat er een NCC zal komen of waar de NCC zich precies mee bezig zal houden; reden waarom wij in de volgende paragraaf eerst de voornaamste kenmerken van de NCC belichten.

\subsection{Kenmerken van de NCC}

De NCC is een nieuw forum voor geschillenbeslechting dat de mogelijkheid biedt om vrijwillig internationale handelsgeschillen in het Engels voor te leggen aan een meervoudige kamer van de NCC en de NCCA, die op snelle en efficiënte wijze zullen werken en waarvan de bekostiging niet ten laste van (de financiële middelen van) de reguliere rechtspraak zal komen. In deze paragraaf lichten wij deze kenmerken toe. Dit is van belang, omdat deze kenmerken een overzicht geven van hoe de NCC er in grote lijnen uit zal komen te zien. Daarnaast biedt een overzicht van de kenmerken de mogelijkheid om in de volgende paragraaf een vergelijking te kunnen trekken met andere fora voor geschillenbeslechting, en zo de nieuwe mogelijkheden van de NCC voor de Nederlandse handelspraktijk te kunnen benadrukken.

Ongetwijfeld een van de meest voorname kenmerken van de NCC is dat er in het Engels wordt geprocedeerd en dat ook in de Engelse taal uitspraak kan worden gedaan. De voertaal van een procedure voor de NCC zal in de regel Engels zijn, maar partijen kunnen verzoeken dat de procedure in de Nederlandse taal wordt gevoerd, in welk geval de NCC ook in het Nederlands uitspraak doet. ${ }^{12}$ De NCC zal worden gehuisvest in het gebouw van het Gerechtshof Amsterdam. Partijen kunnen tegen uitspraken van de NCC hoger beroep instellen bij de NCCA, die eveneens in het gebouw van het Gerechts-

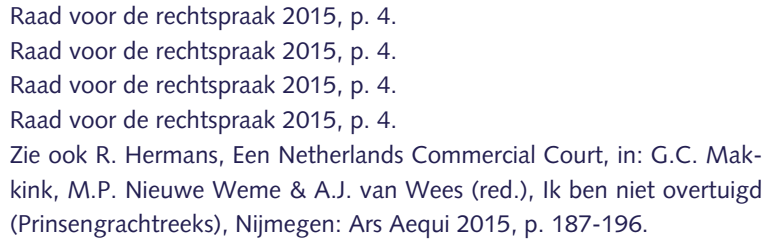

9. Wet houdende wijziging van het Wetboek van Burgerlijke Rechtsvordering en de Wet griffierechten burgerlijke zaken in verband met het mogelijk maken van Engelstalige rechtspraak bij de internationale handelskamers van de Rechtbank en het Gerechtshof Amsterdam, Consultatieversie december 2016

10. Zie <https://wetgevingskalender.overheid.nl/Regeling/WGK007566>, laatstelijk bekeken op 27 maart 2017.

11. Zie <https://netherlands-commercial-court.com/>, laatstelijk bekeken op 27 maart 2017.

12. Zie lid 4 van het voorgestelde art. 30r Rv. 
hof Amsterdam gehuisvest zal worden. ${ }^{13}$ Overal waar wij in dit artikel spreken over de NCC, bedoelen wij ook de NCCA, tenzij wij expliciet anders vermelden.

Er zijn verschillende redenen die hebben bijgedragen aan de keuze voor Gerechtshof Amsterdam als locatie. Allereerst is dit hof gevestigd op een plek die goed te bereiken is voor partijen die uit het buitenland afkomstig zijn door de nabijheid van internationale luchthaven Schiphol. ${ }^{14}$ Ten tweede is Amsterdam een populaire vestigingsplaats voor internationale bedrijven en dit heeft ook het zwaartepunt van de advocatuur in Nederland naar de hoofdstad gebracht. ${ }^{15}$ Een laatste factor in deze beslissing is de beschikbaarheid van moderne (digitale) faciliteiten op deze locatie, die kunnen bijdragen aan een goed verloop van de procedure. ${ }^{16}$ Denk hierbij bijvoorbeeld aan ruimtes om te kunnen skypen of videobellen met partijen die zich niet in Nederland bevinden.

De NCC richt zich op complexe internationale handelsgeschillen in ruime zin. Naast contractuele geschillen gaat het om vorderingen uit onrechtmatige daad, goederenrechtelijke geschillen en vennootschapsrechtelijke kwesties. ${ }^{17}$ Het voorgestelde nieuwe artikel 30r Rv regelt dat partijen kunnen overeenkomen om voor de NCC te procederen in geschillen over rechtsbetrekkingen die ter vrije bepaling van partijen staan (dit betreft vooral handelsgeschillen) en waarvan de rechtbank (of in geval van hoger beroep het gerechtshof) in Amsterdam bevoegd is kennis te nemen. Kantonzaken ${ }^{18}$ zijn uitgezonderd, hetgeen betekent dat zaken met een vordering van ten hoogste $€ 25.000$ en ook geschillen over een consumentenkoop of consumentenkrediet, huurgeschillen, agentuurgeschillen en arbeidsgeschillen buiten de competentie van de NCC vallen.

Een geschil is internationaal indien het een internationaal aspect kent. ${ }^{19}$ Internationaal is in deze context een ruim begrip dat nader wordt uitgewerkt in het NCCprocesreglement. Hiervan zal sprake zijn indien ten minste één van de partijen woonplaats heeft of is gevestigd buiten Nederland, indien de overeenkomst in het buitenland ten uitvoer moet worden gelegd of indien buitenlands recht op het geschil van toepassing is. Het verdient opmerking dat het plan tot oprichting van de commercial court de mogelijkheid openlaat dat Nederlandse partijen ook voor een louter Nederlands geschil zonder internationaal karakter naar de NCC kunnen stappen. ${ }^{20}$ In de openbare consultatieversie van het wetsvoorstel is echter neergelegd dat de NCC-procedure alleen openstaat voor internationale geschillen, en in

13. Wet houdende wijziging van het Wetboek van Burgerlijke Rechtsvordering en de Wet griffierechten burgerlijke zaken in verband met het mogelijk maken van Engelstalige rechtspraak bij de internationale handelskamers van de Rechtbank en het Gerechtshof Amsterdam, 2016, memorie van toelichting, consultatieversie.

14. Memorie van toelichting Wet houdende wijziging 2016, p. 3

15. Memorie van toelichting Wet houdende wijziging 2016, p. 3.

16. Memorie van toelichting Wet houdende wijziging 2016, p. 3.

17. Zie memorie van toelichting Wet houdende wijziging 2016, p. 8.

18. Zaken die op grond van art. $93 \mathrm{Rv}$ aan de kantonrechter moeten worden voorgelegd.

19. Zie memorie van toelichting Wet houdende wijziging 2016, p. 8.

20. Raad voor de rechtspraak 2015, p. 5. de memorie van toelichting daarbij wordt tot tweemaal toe uitdrukkelijk opgemerkt dat de NCC partijen die een puur nationale zaak voorleggen, zal verwijzen naar een andere kamer van de Rechtbank Amsterdam dan wel het Gerechtshof Amsterdam, of naar een ander gerecht indien dat het bevoegde gerecht is. ${ }^{21}$

Partijen kunnen uitsluitend vrijwillig procederen bij de NCC. ${ }^{22}$ Deze vrijwilligheid betekent dat partijen uitdrukkelijk moeten kiezen voor een procedure bij de NCC op het moment dat zij elkaars contractspartij worden, en dus bij het sluiten van het contract, of later, nadat een geschil is ontstaan. ${ }^{23}$ In het voorgestelde artikel 30r Rv wordt neergelegd dat partijen de keuze voor de NCC uitdrukkelijk moeten overeenkomen, en in de memorie van toelichting valt te lezen dat een keuze in algemene voorwaarden die niet door een uitdrukkelijke gezamenlijke keuze wordt gevolgd, zonder rechtsgevolg blijft. $^{24}$

Een volgend kenmerk van de NCC is dat elke zaak, zowel in eerste aanleg als in hoger beroep, zal worden behandeld door drie gespecialiseerde rechters. ${ }^{25}$ Dit is een onderscheidend kenmerk voor de NCC ten opzichte van andere commercial courts. Daar kunnen zaken ook door één rechter worden behandeld. ${ }^{26}$ Zo beslissen rechters in het commercial court in Dubai bijvoorbeeld in eerste aanleg altijd alleen. ${ }^{27}$

Een ander kenmerk waarmee de NCC zich wil onderscheiden van andere commercial courts, is het streven om de procedures bij de NCC altijd snel en efficiënt te laten verlopen. Het plan is om dit te realiseren door een combinatie van het Nederlandse procesrecht en best practices van andere commercial courts toe te passen op de procedure, en gebruik te maken van de moderne faciliteiten van het Gerechtshof Amsterdam om bijvoorbeeld ook digitaal te kunnen overleggen met partijen.

Een belangrijk streven is dat de NCC kostenneutraal is. ${ }^{28}$ De inbedding van de NCC en de NCCA in het gebouw en de organisatie van het Gerechtshof Amsterdam draagt in sterke mate aan dit streven bij. Daarnaast betekent dit streven ook dat griffiekosten die geheven worden voor het procederen bij de NCC hoger liggen dan bij andere (civiele) procedures voor een Nederlandse rechter. De achterliggende redenering is dat hogere griffiekosten zorgen dat de totale kosten van de rechter-

21. Memorie van toelichting Wet houdende wijziging 2016, p. 8-9.

22. Zie het voorgestelde art. 30r lid $1 \mathrm{Rv}$, alsook memorie van toelichting Wet houdende wijziging 2016, p. 8.

23. Hermans 2015, p. 187-196.

24. Zie het voorgestelde art. 30r lid $1 \mathrm{Rv}$, alsook memorie van toelichting Wet houdende wijziging 2016, p. 3.

25. Jurisdiction in the Netherlands over Commercial Cases, via <http:// netherlands-commercial-court.com/jurisdiction-netherlands.html>, alsook Raad voor de rechtspraak 2015, p. 9.

26. E. Bauw, Over de kansen van een Netherlands Commercial Court, Ars Aequi 2016/2, p. 96.

27. M. Hwang, The Courts of the Dubai International Finance Centre - A Common Law island in a Civil Law ocean (DIFC Courts, 1 november 2008), <http://difccourts.ae/the-courts-of-the-dubai-internationalfinance-centre-a-common-law-island-in-a-civil-law-ocean/>.

28. Memorie van toelichting Wet houdende wijziging 2016, p. 6. 
lijke macht niet omhoog gaan en het reguliere budget niet geraakt wordt, waardoor de NCC geen invloed heeft op de begroting en dus als budgetneutraal kan worden gezien. ${ }^{29}$ Zo zal de oprichting van de NCC geen negatieve impact hebben op de reguliere rechtsprocedures in Nederland.

Een kanttekening kan worden gemaakt voor het geval het bereik van de NCC de Europese Unie en omringende landen overstijgt. Dan kunnen bij de tenuitvoerlegging van vonnissen van de NCC problemen ontstaan. Stel bijvoorbeeld dat een Amerikaanse, Turkse of Russische gedaagde wel voor de NCC verschijnt, maar vervolgens het vonnis aan zijn laars lapt en zich in eigen land verschanst. Als er sprake zou zijn geweest van internationale arbitrage, zou het Arbitrageverdrag van New York uitkomst bieden. ${ }^{30}$ Bij dit verdrag, dat regels bevat over de erkenning van arbitrageovereenkomsten door nationale gerechten en de tenuitvoerlegging van buitenlandse arbitrale uitspraken, zijn 144 partijen aangesloten, waaronder de VS, Turkije en Rusland. ${ }^{31}$ Een arbitragevonnis kan dus in grote delen van de wereld ten uitvoer worden gelegd. Bij de tenuitvoerlegging van uitspraken van overheidsrechters zoals die van de NCC ligt dit anders. De tenuitvoerlegging hiervan is geregeld in de EEX II-Verordening. ${ }^{32}$ Dit is een Europese verordening die regelt dat vonnissen in principe in alle EU-landen ten uitvoer kunnen worden gelegd. Door verschillende verdragen zijn dergelijke vonnissen EER-breed, dus in de Europese Unie, Noorwegen, IJsland, Zwitserland en Lichtenstein, ${ }^{33}$ uitvoerbaar, en daarnaast ook in Suriname. ${ }^{34}$ Dit zijn echter de enige landen waarmee dergelijke overeenkomsten over tenuitvoerlegging van vonnissen zijn gesloten. ${ }^{35}$ Dit is dus in vergelijking tot internationale arbitrage een belangrijk nadeel van de NCC. Benadrukt zij evenwel dat dit nadeel niet uniek voor de NCC geldt. De mogelijke problemen die zich bij wereldwijde tenuitvoerlegging voor kunnen doen, spelen evenzeer bij de tenuitvoerlegging van andere vonnissen van zowel gewone als commercial courts hier te lande en daarbuiten. Desalniettemin is het goed om dit praktische aspect in gedachten te houden bij een keuze tussen internationale arbitrage of een commercial court.

29. Memorie van toelichting Wet houdende wijziging 2016, p. 1.

30. Verdrag tot erkenning en tenuitvoerlegging van buitenlandse arbitrale vonnissen van 10 juni 1958.

31. Zie <www.newyorkconvention.org/countries $>$ en $<w w w$. newyorkconvention.org/countrieshttp://www.newyorkconvention.org/ countries>.

32. Regulation (EU) No 1215/2012 of the European Parliament and of the Council of 12 December 2012 on jurisdiction and the recognition and enforcement of judgments in civil and commercial matters.

33. Besluit 2007/712/EG van de Raad van 15 oktober 2007 inzake de ondertekening namens de Gemeenschap van het Verdrag betreffende de rechterlijke bevoegdheid, de erkenning en de tenuitvoerlegging van beslissingen in burgerlijke en handelszaken (het Verdrag van Lugano).

34. Overeenkomst tussen het Koninkrijk der Nederlanden en de Republiek Suriname betreffende de wederzijdse erkenning en de tenuitvoerlegging van rechterlijke beslissingen en authentieke akten in burgerlijke zaken.

35. Volledigheidshalve zij nog gewezen op de overeenkomst tussen de EU en Denemarken over de erkenning en tenuitvoerlegging van beslissingen in burgerlijke zaken. In verband met de opt-in die Denemarken in 1992 heeft bedongen, geldt dat Denemarken niet meedoet, tenzij..
Concluderend vallen de voornaamste kenmerken van de NCC samen te vatten in één zin. De NCC is een nieuw forum voor beslechting van internationale handelsgeschillen dat de mogelijkheid biedt om na een uitdrukkelijke keuze daarvoor een procedure te voeren in de Engelse taal bij een meervoudige kamer in eerste aanleg en hoger beroep, waarbij op snelle, efficiënte en kostenneutrale wijze wordt gewerkt. Hiermee is voldoende duidelijk wat de NCC is en waarmee de NCC zich bezig zal houden, zodat wij in de volgende paragraaf kunnen overgaan tot het bespreken van de voordelen van de NCC voor de contractspraktijk aan de hand van de gang van zaken en de procedure bij de NCC.

\section{De positieve mogelijkheden van de NCC per onderdeel van de procedure}

\subsection{Aanpak}

De gang van zaken bij de NCC is voor een deel hetzelfde als de gang van zaken bij elke andere Nederlandse rechtbank. Er zijn echter ook diverse verschillen, die wij hierna inzichtelijk maken. Aan de hand van de procedure bij de NCC bespreken wij welke nieuwe mogelijkheden de NCC biedt voor de Nederlandse rechtspraktijk, en waar nodig trekken wij ook vergelijkingen met andere commercial courts, waaronder in het bijzonder de London Commercial Court (LCC), nu daarmee de meeste concurrentie te verwachten is. ${ }^{36} \mathrm{Wij}$ houden hierbij zo veel mogelijk de chronologische volgorde van een procedure bij de NCC aan. Om te beginnen gaan wij in paragraaf 3.2 in op de vraag naar het toepasselijke materiële recht. Hierna stellen wij in paragraaf 3.3 ook aan de orde of het Nederlandse recht aantrekkelijk is en of het waarschijnlijk is dat partijen voor toepassing van het Nederlandse recht zullen kiezen. Vervolgens bespreken wij in de paragrafen die daarop volgen (3.4 tot en met 3.7$)$ het procesrecht dat van toepassing is. Daarbij belichten wij de nieuwe mogelijkheden die het programma 'Kwaliteit en Innovatie' (hierna: KEI) kan bieden bij het opstarten en inrichten van het proces. Ten slotte zoomen wij in op een aantal procedurele aspecten van de NCC in eerste en tweede aanleg, te weten de behandeling door een meervoudige kamer, de mogelijkheid om prejudiciële vragen te stellen en de aan de procedure verbonden kosten voor partijen.

\subsection{Hoe forumkeuze en rechtskeuze samengaan}

Zoals hiervoor al is aangestipt, is het allereerst van belang om te weten welk recht van toepassing zal zijn op een procedure bij de NCC. Dit toepasselijke recht valt uiteen in het materiële en processuele recht. Het eerste

36. H.N. Schelhaas, De markt op met de Nederlandse rechtsorde?, NTBR 2017/3, wijst erop dat de Brexit ervoor kan zorgen dat de tenuitvoerlegging van Engelse uitspraken in de toekomst problematischer wordt, hetgeen de populariteit van een Nederlands commercial court kan vergroten boven het bestaande commercial court in Londen. 
vindt bespreking in deze en de volgende paragraaf, het toepasselijke procesrecht komt in de daarop volgende paragrafen aan bod.

De keuze voor het materiële recht dat van toepassing is op het internationale handelsgeschil, staat in beginsel vrij aan de contractspartijen. Het is dus mogelijk dat de NCC te maken krijgt met geschillen waarop buitenlands recht van toepassing is ${ }^{37}$ doordat het contract gesloten is met een rechtskeuze voor, bijvoorbeeld, Engels recht. Echter, vooralsnog ligt het voor de hand dat partijen alleen voor de NCC zullen kiezen indien Nederlands materieel recht van toepassing is. ${ }^{38}$ Natuurlijk kan dit ook anders zijn, maar het is een redelijke aanname dat partijen, indien zij er bijvoorbeeld voor kiezen om common law toe te passen op hun geschil, ook naar een commercial court gaan dat ligt in een land waar common law het toepasselijke recht is.

Het feit dat een forumkeuze in de praktijk vaak hand in hand gaat met een keuze voor het toepasselijke recht, werkt in het voordeel van de commercial courts in common law-landen en zou een barrière kunnen vormen voor de keuze voor de NCC. ${ }^{39}$ Immers, daar waar common law over het algemeen wordt gezien als zeer antrekkelijk voor de beslechting van internationale handelsgeschillen, omdat het als zeer betrouwbaar en rechtszeker wordt beschouwd, ${ }^{40}$ wordt Nederlands (contracten)recht gezien als minder aantrekkelijk, vooral doordat het in sterke mate door de redelijkheid en billijkheid wordt beheerst.

Op deze ervaring van onaantrekkelijkheid van het Nederlandse recht is echter wel het nodige af te dingen. De verschillen in rechtszekerheid tussen het Engelse recht en het Nederlandse recht zijn namelijk minder groot dan ze worden afgeschilderd. ${ }^{41}$ Het Nederlandse contractenrecht is rechtszekerder dan gedacht, en het Engelse contractenrecht is juist minder rechtszeker dan partijen vaak aannemen. ${ }^{42}$ Het Nederlandse contractenrecht is te vinden in een systematisch Burgerlijk Wetboek, waarin ook de maatstaven van de redelijkheid en billijkheid zijn gecodificeerd. Daartegenover is het Engelse recht te vinden in een wirwar van rechterlijke uitspraken waarvan het belang niet altijd helder is als gevolg van het formele systeem van precedentwerking.

In de Nederlandse rechtspraktijk worden de juridische effecten van een contract mede aan de hand van de redelijkheid en billijkheid vastgesteld. Een afspraak die tussen partijen als bindend wordt beschouwd, kan op basis van een beroep op redelijkheid en billijkheid toch buiten

37. Raad voor de rechtspraak 2015, p. 10.

38. Bauw 2016, p. 98.

39. Bauw 2016, p. 98; Tjittes 2014, p. 261.

40. 2010 International Arbitration Survey: Choices in International Arbitration, School of International Arbitration van de Queen Mary University of London (onder leiding van prof. L. Mistelis), in opdracht van White \& Case, p. 13.

41. J.G.J. Rinkes, Reasonable expectations of honest men. Over privaatrecht, contractenrecht en vertrouwen, Rede bij de openbare aanvaarding van het ambt van hoogleraar privaatrecht aan de OUN, 2005, p. 3.

42. R.P.J.L. Tjittes, Een Netherlands Commercial Court vereist reclame voor Nederlands recht, RMThemis 2014, p. 262. beschouwing worden gelaten. Het Engelse contractenrecht daarentegen staat meer vijandig tegenover een algemeen leerstuk van good faith. ${ }^{43}$ Een van de argumenten hiervoor is dat hantering van een dergelijk principe zou leiden tot rechtsonzekerheid, ${ }^{44}$ omdat een rechtbank of hof bij het toepassen van het concept goede troum de mogelijkheid heeft om vage en subjectieve standaarden op een contractuele verplichting toe te passen. ${ }^{45}$ Het feit dat het Engelse contractenrecht geen algemeen leerstuk van de goede trouw kent, betekent echter niet dat alles mogelijk is in het Engelse contractenrecht. Er bestaan wel degelijk doctrines die de rechter de mogelijkheid geven om bepaalde afspraken aan te passen of nietig te verklaren. Deze mogelijkheid wordt met name gecreëerd door het principe van contractual fairness. En in dit principe is de reden te vinden waarom het Nederlandse recht nog niet zo gek hoeft te zijn. Problematisch aan het begrip van contractual fairness is namelijk dat er geen vastomlijnde betekenis van dit principe bestaat. ${ }^{46}$ Dit kan dus leiden tot een enorme variëteit in uitspraken. In Nederland daarentegen is, onder meer door de uitgebreide jurisprudentie over redelijkheid en billijkheid, de betekenis daarvan relatief duidelijk, hetgeen de rechtszekerheid heeft vergroot. ${ }^{47}$ Dit kan voor partijen dus juist een voordeel zijn bij de NCC, angezien het dan duidelijk is wat zij kunnen verwachten op basis van redelijkheid en billijkheid.

\subsection{Keuze voor Nederlands recht}

Naast het feit dat het onzes inziens een redelijke aanname is dat partijen die opteren voor de NCC er ook voor kiezen om Nederlands recht van toepassing te laten zijn, is dit ook essentieel voor het succes en het waarborgen van de kwaliteit van de NCC. Die kwaliteit kan alleen bij toepassing van Nederlands recht ten volle worden gewaarborgd, omdat bij de NCC alleen Nederlandse rechters werken, die voornamelijk ervaren zijn in het toepassen van Nederlands recht. Hun expertise kan dan ook in het bijzonder tot volle uiting komen wanneer zij Nederlands recht toepassen.

Voor succes van de NCC is dus de vraag van belang of partijen zullen millen kiezen voor het Nederlandse recht. Om deze vraag te kunnen beantwoorden is het van belang om te weten op grond van welke redenen partijen voor een bepaald rechtssysteem kiezen. Uit enkele enquêtes onder internationale bedrijven blijkt dat de meerderheid voor Engels recht kiest, omdat dit recht

43. Interfoto Picture Library Ltd/Stiletto Visual Programmes Ltd (1989) QB 433, CA 14-15, zie par. 439 (Lord Bingham).

44. E. McKendrick, Contract Law. Text, Cases, and Materials, Oxford: Oxford University Press 2016, p. 495-497.

45. White \& Carter /McGregor (1962), AC 413, HL, par. 460-461 (Lord Reid).

46. In een zaak uit 2014 van de Chancery Division werd bijvoorbeeld gesproken over een 'duty of faith' die werd verondersteld in een commerciële duurovereenkomst. Dit kwam sterk in de buurt van het principe van de redelijkheid en billijkheid zoals dat in Nederland bestaat. Zie: Bristol Groundschool Ltd/Intelligent Data Capture Ltd \& Ors (2014), EWHC 2145 (Ch); Bauw 2016, p. 98.; R.P.J.L. Tjittes, Op de golven van de goede trouw naar Engels contractenrecht, RM Themis 2015/5, p. 1-2.

47. Tjittes 2014, p. 261-262. 
volgens de respondenten de meeste zekerheid biedt. ${ }^{48}$ Terwijl contractanten onder omstandigheden een groter belang hechten aan rechtszekerheid dan aan bescherming ${ }^{49}$ weegt echter de redelijkheid van het contractenrecht voor het bedrijfsleven naar verluidt in abstracto zwaarder dan voorspelbaarheid of rechtszekerheid. Gevraagd naar de eisen die het bedrijfsleven in het algemeen aan het contractenrecht stelt, scoort de redelijkheid met een cijfer van 8,5 op een schaal van 10 het hoogst, gevolgd door de voorspelbaarheid/rechtszekerheid met een $8,21 .{ }^{50}$ Uit onderzoek blijkt dat de belangrijkste redenen voor bedrijven om voor een bepaald recht te kiezen zijn: neutraliteit en onpartijdigheid van het toepasselijke recht, de geschiktheid van het toepasselijke recht voor de overeenkomst die zij gesloten hebben, en de bekendheid en ervaring met het desbetreffende rechtsstelsel, aldus Tittes. ${ }^{51}$ Deze laatste factor, bekendheid en ervaring met het rechtsstelsel, kan uiteraard alleen ontstaan door gebruik te maken van het Nederlandse recht en is in die zin niet heel relevant om partijen over te halen om te kiezen voor toepassing van het Nederlandse contractenrecht. Positief feit is wel dat Nederlands recht voor veel internationale bedrijven niet geheel onbekend is, nu immers de nodige internationale bedrijven een holding of vennootschap in ons land hebben. ${ }^{52}$ Evenwel nog belangrijker is dat de eerste twee factoren aspecten zijn waar de NCC zeker zijn voordeel mee kan doen. Het Nederlandse recht wordt over het algemeen gezien als zeer neutraal en onpartijdig. ${ }^{53}$ Daarnaast kan het uitgebreide Nederlandse contractenrecht met alle bijbehorende jurisprudentie ook zeker als geschikt worden gezien. Wij achten de kans dat partijen voor het Nederlandse recht willen kiezen, op basis van deze statistieken, dan ook niet onaanzienlijk.

\subsection{NCC-procesregels}

Nederlands recht kan aldus als het materiële recht worden gekozen dat van toepassing is bij de NCC. Wat betreft het processuele recht dat van toepassing is, liggen de zaken anders. Partijen hebben hier geen invloed op, want het procesrecht dat de NCC zal toepassen staat vast. Dit zijn namelijk de speciaal voor de NCC ontwikkelde NCC-regels. Deze regels zullen grotendeels gestuurd worden door het Nederlandse procesrecht, waardoor het procesrecht voor de NCC goeddeels overeen zal komen met het procesrecht dat alle andere gerechten in Nederland toepassen. Over het algemeen wordt het Nederlandse procesrecht gezien als efficiënt, snel en voorspelbaar. ${ }^{54}$ De NCC-regels verwijzen echter

48. G. Cordero-Moss, Interpretation of Contracts in International Commercial Arbitration: Diversity in More than One Level, ERPL 2014/1, p. 27. Zie ook Schelhaas 2017.

49. M. Hurenkamp \& $M$. Kremer (red.), Vrijheid verplicht: over tevredenheid en de grenzen van keuzevrijheid, Amsterdam: Van Gennep 2005.

50. Tjittes 2014, p. 261

51. Tjittes 2014, p. 261.

52. Tjittes 2014 , p. 261

53. Tjittes 2014, p. 261-262.

54. Raad voor de rechtspraak 2015, p. 10; P.E. Ernste \& F.E. Vermeulen, The Netherlands Commercial Court - an attractive venue for international commercial disputes?, TCR 2016/, p. 127-137, i.h.b. p. 128; Bauw 2016, p. 98. niet alleen maar naar Nederlandse regels van procesrecht. Dit Nederlandse recht kan worden aangevuld met andere regels, die vooral ten doel hebben om de kwaliteit en efficiëntie van NCC-procedures te waarborgen. ${ }^{55}$ $\mathrm{Om}$ dit te bereiken zullen bijvoorbeeld best practices van andere commercial courts kunnen worden toegevoegd, zoals de wijze waarop getuigen- en deskundigenverhoren worden vastgelegd in de LCC. ${ }^{56}$ De voornaamste doelen hiervan zijn om het proces efficiënter te laten verlopen of internationale partijen meer vertrouwd te laten voelen met de procedure. ${ }^{57}$

Alhoewel nog niet openbaar is gemaakt hoe de NCCregels er precies uit zullen zien, is dit een veelbelovend vooruitzicht. De regels beogen een snelle en efficiënte procedure te garanderen, waarbij ook ruimte is voor de behoeftes van buitenlandse partijen. Dit zou ervoor kunnen zorgen dat internationale partijen eerder geneigd zijn om te kiezen voor de NCC, of sneller tevreden zijn wanneer zij voor de NCC hebben gekozen.

$\mathrm{Nu}$ wij weten welk recht er van toepassing zal zijn op de procedures bij de NCC, kunnen wij een aantal opvallende aspecten van de procedure bij de NCC aanstippen. Aangezien wij deze punten in chronologische volgorde behandelen, aan de hand van de procedure, beginnen wij bij het indienen van de processtukken. De verwachting is dat dit bij de NCC geheel digitaal zal gebeuren. Dit komt door de invoering van het programma KEI. Dit programma is ontstaan vanuit de wens om de rechtspraak in Nederland meer toegankelijk en begrijpelijk te maken voor rechtzoekenden en alle andere betrokken partijen. ${ }^{58}$ De invoering van het programma KEI kan dit bewerkstelligen door de procedures sneller, eenvoudig en toegankelijk te maken. Middelen om dit te bereiken zijn onder meer een versterkte regierol voor de rechter, de mogelijkheid om de rechtspraak (voornamelijk het dossier) digitaal te bezoeken en daarmee ook bijvoorbeeld de mogelijkheid om digitaal verweer te voeren. Al deze veranderingen zullen de procedure en de gang van zaken bij de rechter ingrijpend veranderen. Denk bijvoorbeeld aan de genoemde doelen om zaken digitaal toegankelijk te maken, de duur van rechtszaken met gemiddeld $40 \%$ te verkorten, papieren dossiers te vervangen door digitale, en meer tijd te creëren voor complexe zaken. ${ }^{59}$

Voor de NCC zien wij positieve gevolgen verbonden aan de invoering van KEI. ${ }^{60}$ De KEI-wetsvoorstellen voeren een nieuwe eenvoudige basisprocedure in die, zodra de aard van de zaak dat verlangt, kan worden uitgebreid met andere proceshandelingen waardoor maatwerk kan worden geboden, ook in complexe en omvangrijke internationale handelsgeschillen. ${ }^{61}$ Daar KEI de regierol van de rechter versterkt, zal de rechter waar nodig meer stu-

55. Bauw 2016, p. 96.

56. Raad voor de rechtspraak 2015, p. 11.

57. Ernste \& Vermeulen 2016, p. 128.

58. Zie <www.rechtspraak.nl/kei>

59. Presidenten Raad Overleg, Meerjarenplan van de Rechtspraak 2015-2020, 2015, p. 5.

60. Memorie van toelichting Wet houdende wijziging 2016, p. 5.

61. Raad voor de rechtspraak 2015, p. 11. 
ring aan de procedure geven, onder mee door in een vroegtijdig stadium overleg met partijen te voeren. Voor internationale partijen, althans hun juridische vertegenwoordigers, kan het een groot voordeel zijn om online een procedure te kunnen starten, een verweer te kunnen voeren, stukken te kunnen indienen en inzien, en de voortgang van de procedure te kunnen volgen. ${ }^{62}$ Dit bespaart tijd en kosten. Ook vergroot de mogelijkheid om digitaal te procederen het gebruiksgemak van de NCC. ${ }^{63}$ KEI en de NCC zijn sterk met elkaar verbonden, waarbij de kwaliteit, de efficiëntie en het gebruiksgemak van de NCC gewaarborgd worden door de invoering van KEI.

\subsection{De gang naar de NCC-rechters}

$\mathrm{Na}$ het digitaal indienen van een zaak via KEI kan de procedure bij de NCC beginnen. Een aantal punten onderscheiden de procedure bij de NCC van die bij andere fora voor beslechting van internationale geschillen. Achtereenvolgens gaan wij in op de behandeling door een meervoudige kamer en de mogelijkheid tot het stellen van prejudiciële vragen. Een derde element, de kosten van het procederen bij de NCC, wordt hierna in paragraaf 3.6 besproken.

Naar verluidt zullen alle zaken bij de NCC, zowel in hoger beroep als in eerste aanleg, worden behandeld door een meervoudige kamer, bestaande uit drie rechters ${ }^{64}$ Dit is anders dan standaard het geval is, zowel in Nederland als bij andere commercial courts. In Nederland wordt meer dan $90 \%$ van de gewone civiele zaken in eerste aanleg door één rechter afgedaan. Voor de NCC wordt dit anders, hetgeen tot waardering zal leiden in vergelijking tot de praktijk bij andere commercial courts. In Londen bijvoorbeeld, net als bij andere common law commercial courts, worden de zaken door een enkelvoudige kamer behandeld ${ }^{65} \mathrm{Nu}$ er in de literatuur verschillende voordelen van meervoudige behandeling ten opzichte van behandeling door een enkelvoudige kamer zijn te vinden, kunnen aan deze vernieuwing voor de NCC belangrijke voordelen worden toegeschreven. ${ }^{66} \mathrm{Zo}$ leidt een meervoudige behandeling over het algemeen

62. Zie www.rechtspraak.nl/kei, laatstelijk bekeken op 15 maart 2017.

63. Opgemerkt zij dat voor gebruikmaking van de faciliteiten van KEI een advocatenpas noodzakelijk is. Dit is omdat advocaten slechts kunnen inloggen bij de Rechtspraak met zo'n pas. Zie <www.advocatenorde.nl/ 3837/advocaten/advocatenpas>, laatstelijk bekeken op 27 maart 2017. Deze pas kan worden aangevraagd wanneer een advocaat in Nederland beëdigd is. Buitenlandse advocaten die niet beschikken over een advocatenpas, zullen dus geen stukken kunnen uploaden in het dossier. Wij verwachten echter niet dat dit grote problemen zal opleveren. Allereerst is het op dit moment ook niet mogelijk dat een buitenlandse advocaat stukken aanlevert voor het procesdossier en voor een Nederlands gerecht procedeert. Dit kunnen in Nederland beëdigde advocaten als vertegenwoordiger van buitenlandse partijen doen. Daarnaast kan dit ook worden gezien als een voordeel voor de Nederlandse procespraktijk, nu er altijd in Nederland beëdigde advocaten moeten worden betrokken bij een procedure voor de NCC.

64. Raad voor de rechtspraak 2015, p. 11; Bauw 2016, p. 96

65. Bauw 2016, p. 96.

66. Zie voor een goed overzicht van literatuur en argumenten: R. Baas, L. de Groot-van Leeuwen \& M. Laemers, Rechtspreken: samen of alleen. Over meervoudige en enkelvoudige rechtspraak, Den Haag: Sdu Uitgevers 2010, hoofdstuk 3 tot een kwalitatief betere uitspraak, angezien er meer discussie is geweest tussen rechters onderling. Verder blijken uitspraken gedaan door een meervoudige kamer meer gezag te hebben en daarmee eerder te worden aanvaard door procespartijen. Als laatste kan de meervoudige behandeling gezien worden als een betere waarborg voor onpartijdigheid. Het feit dat binnen de NCC alle zaken door een meervoudige kamer worden behandeld, kan dus zowel bijdragen aan de kwaliteit als aan een grotere acceptatie van de uitspraken van de NCC. Dit zijn belangrijke zaken, die kunnen bijdragen aan een groter vertrouwen in de NCC en die het gezag van de NCC kunnen vergroten.

Een volgende mogelijkheid van de procedure bij de NCC kan ook bijdragen aan het vergroten van het gezag en de acceptatie van zaken. Dit is de mogelijkheid voor de rechters van de NCC om, zowel in eerste als in tweede anleg, prejudiciële vragen te stellen aan de Hoge Raad. Deze mogelijkheid is wel begrensd, in die zin dat rechters niet over alle onderdelen van de procedure vragen kunnen stellen. Het moet namelijk een principiële rechtsvraag betreffen die van belang is voor de uiteindelijke beslissing in de zaak die voor de NCC dient. Toch zien wij de mogelijkheid tot het stellen van prejudiciële vragen als een belangrijk voordeel van de NCC ten opzichte van andere commercial courts. In andere commercial courts bestaat deze mogelijkheid namelijk vaak niet, waardoor soms lang moet worden voortgeprocedeerd om een bepaalde rechtsvraag definitief te beantwoorden. Dit kan leiden tot lange en kostbare procedures. ${ }^{67}$

Opmerking verdient evenwel dat de prejudiciële vragen, in tegenstelling tot de andere elementen van het proces voor de NCC, in het Nederlands zullen worden gesteld en behandeld. ${ }^{68}$ Dit kan een minpunt zijn voor buitenlandse partijen, omdat zij de voor een prejudiciële procedure vereiste taalkennis niet altijd zullen bezitten. Echter, dit zal niet een onoverkomelijk probleem vormen. De Hoge Raad accepteert namelijk wel Engelstalige processtukken ${ }^{69}$ waardoor het mogelijk is voor internationale partijen om stukken eenvoudig aan te leveren zonder tijd en geld in het vertalen van deze stukken te hoeven stoppen. Dit zorgt ervoor dat hun kosten niet onnodig oplopen.

Niet alleen heeft de mogelijkheid van een tussentijdse beantwoording van een rechtsvraag door de Hoge Raad een kostenverlagend effect in vergelijking tot het moeten doorprocederen in andere landen, ook liggen andere kosten van een proces bij de NCC een stuk lager dan in internationale arbitrage en bij andere commercial courts. Dit vormt een volgend belangrijk punt, waarover nu meer.

67. Bauw 2016, p. 96.

68. Memorie van toelichting Wet houdende wijziging 2016, p. 6. Kritisch hierover is C.E. Drion, Drafting tips \& skills: de Netherlands Commercial Court, ORP 2017/2, p. 76

69. Memorie van toelichting Wet houdende wijziging 2016, p. 6. 


\subsection{Kosten voor partijen}

Uit onderzoek dat in opdracht van de Raad voor de rechtspraak is uitgevoerd, is gebleken dat de totale kosten van een Angelsaksische procedure gemiddeld het vijfvoudige bedragen van een Nederlandse procedure. ${ }^{70}$ In het bijzonder wat betreft de kosten voor de verzameling van bewijsstukken bestaan grote verschillen tussen landen. Deze liggen in Nederland aanzienlijk lager dan in sommige andere landen, zoals Engeland en de Verenigde Staten, omdat het Nederlands procesrecht een minder uitgebreide exhibitieplicht kent dan bijvoorbeeld het Engelse disclosure of het Amerikaanse discovery. ${ }^{71}$ Het valt buiten de reikwijdte van dit artikel om in detail in te gaan op deze plichten. Hier volstaat de boodschap dat de aan fact finding verbonden kosten in Nederland in vergelijking laag zijn, met een korte uitleg van de gevolgen van deze minder uitgebreide exhibitieplicht en waarom dit tot lagere kosten leidt. In grotere zaken kan het verzamelen van bewijsstukken in de Engelse en Amerikaanse procespraktijk soms wel een jaar tijd in beslag nemen. Vervolgens wordt tijdens de zitting veel tijd besteed aan het ondervragen van getuigen over de verzamelde bewijsstukken. Doordat er in het Nederlandse procesrecht een duidelijke grens is met betrekking tot de bewijsstukken die de wederpartij moet verschaffen, zal er minder tijd in dit proces gaan zitten, hetgeen ook de kosten drukt. ${ }^{72}$

De algehele kosten van procederen in Nederland worden ook gedrukt doordat de gemiddelde kosten voor de inzet van een advocaat in Nederland een stuk lager liggen dan bijvoorbeeld in Engeland. ${ }^{73}$ Dit biedt kansen voor de NCC, aangezien lagere advocatenkosten tot een forse besparing van de totale proceskosten leiden. De Raad voor de rechtspraak becijferde in 2015 dat het procederen bij de NCC in vergelijking tot de LCC naar verwachting een besparing van advocaatkosten oplevert van $€ 35$ miljoen per jaar bij 125 zaken. ${ }^{74}$ Daarbij is gerekend met een besparing van $€ 600.000$ tot $€ 2,4$ miljoen per partij.

De kosten van procederen bij de NCC zullen dus aanzienlijk lager uitvallen dan bij andere commercial courts. Echter, er zijn ook kosten die in Nederland juist hoger zijn dan in andere landen. Zo bestaan er bijvoorbeeld aanzienlijke verschillen tussen de griffiekosten van de NCC en de LCC. In de consultatieversie van het wetsvoorstel betreffende de oprichting van de NCC worden de griffiekosten in eerste anleg op $€ 15.000$ vastgesteld, en in tweede anleg op $€ 20.000 .{ }^{75} \mathrm{Bij}$ de LCC zijn deze

70. Raad voor de rechtspraak 2015, p. 17.

71. Bauw 2016, p. 96.

72. Bauw 2016, p. 96.

73. Raad voor de rechtspraak 2015, p. 7, 17

74. De ruime variatie in deze getallen hangt af van hoe ver er geprocedeerd wordt in een geschil (tussentijdse schikking of eindvonnis). Raad voor de rechtspraak 2015, p. 17.

75. Consultatieversie december 2016, Wet houdende wijziging van het Wetboek van Burgerlijke Rechtsvordering en de Wet griffierechten burgerlijke zaken in verband met het mogelijk maken van Engelstalige rechtspraak bij de internationale handelskamers van de Rechtbank en het Gerechtshof Amsterdam, art. 2 kosten aanzienlijk lager: daar betaalt iedere partij minder dan $€ 2.000$ aan griffiekosten. ${ }^{76}$ De lage griffiekosten bij de LCC zijn momenteel echter wel punt van discussie, angezien er plannen circuleren om de griffiekosten voor de LCC sterk te verhogen, tot $5 \%$ van de waarde van de claim voor vorderingen boven $f 40.000$, met een maximumbedrag van $f 15.000$ of $f 20.000 .{ }^{77}$ Waarom deze plannen precies zijn ontstaan, is onduidelijk; het zou er mee te maken kunnen hebben dat procespartijen bij de LCC een groter deel van hun eigen kosten moeten dragen omdat ze daar financieel toe in staat zijn. ${ }^{78}$ Echter, het is nog maar zeer de vraag of deze plannen uiteindelijk worden uitgevoerd, aangezien ze op veel weerstand stuiten. ${ }^{79}$ Gevreesd wordt dat een dergelijke verhoging de internationale positie van Engeland als dé plek voor internationale geschillenbeslechting niet ten goede zal komen. ${ }^{80}$ Voorlopig kunnen wij dus met zekerheid zeggen dat de griffiekosten bij de NCC aanzienlijk hoger liggen dan in andere landen zoals Engeland. ${ }^{81}$ Toch zien wij hier geen grote problemen voor de NCC. De griffiekosten zijn namelijk slechts een gering deel van de totale kosten van een procedure. Het ligt niet in de lijn der verwachtingen dat deze kosten de bepalende factor zullen zijn in een keuze voor of tegen de NCC. ${ }^{82}$

\subsection{Positieve evaluatie}

Op basis van het voorgaande kunnen wij concluderen dat de kenmerken van en de procedure bij de NCC positief uit kunnen pakken voor Nederlandse (contracts)partijen. Voordelen zijn onder meer de behandeling in de Engelse taal, een goed aangepast procesreglement, beslechting door een meervoudige kamer, de digitale procedure van het programma KEI, de mogelijkheid om prejudiciële vragen te stellen en last but not least relatief lage kosten.

Wie dit zo achter elkaar ziet, zou kunnen concluderen dat succes voor de NCC gegarandeerd is. Daarover denken wij echter anders. Hoewel het duidelijk is dat er voordelen aan de NCC verbonden zijn ten opzichte van andere fora voor internationale geschillenbeslechting, garandeert dit niet dat de NCC een succes gaat worden. Natuurlijk is het wel een mooi uitgangspunt, want als bijvoorbeeld de procedure of het toepasselijke recht reeds grote nadelen in zich zou bergen, zou de kans op succes kleiner zijn. Toch zal er, om de NCC een succes te laten zijn, veel moeten gebeuren. In de volgende para-

76. Bauw 2016, p. 98

77. Bauw 2016, p. 98.

78. Zie <www.theguardian.com/law/2015/jan/19/dramatic-increases-court -fees-deep-concern-senior-judges>, laatstelijk bekeken op 27 maart 2017.

79. J. Croft, Judges attack planned rise in commercial court fees, Financial Times 2015, <www.ft.com/content/cc8d5b66-9fd1-11e4-aa89 $-00144 \mathrm{feab7de>}$.

80. Bauw 2016, p. 98.

81. Opgemerkt zij evenwel dat in andere landen de entry fee weliswaar betrekkelijk laag kan zijn, maar dat er dan per verrichting moet worden bijbetaald, terwijl in Nederland een vaste prijs geldt, ongeacht het verloop en de duur van de procedure.

82. Raad voor de rechtspraak 2015, p.15-16. 
graaf taxeren wij welke stappen nog genomen dienen te worden om de NCC tot een succes te maken.

\section{Sleutel tot succes}

De positieve punten van de NCC zijn hiervoor de revue gepasseerd, maar om de NCC tot een succes te maken is meer nodig dan de aanwezigheid van de juiste ingrediënten voor succes binnen de NCC. Bij het invoeren van een nieuwe keuzemogelijkheid is het essentieel dat er wordt nagegaan wat ervoor zorgt dat men ook daadwerkelijk een nieuwe keuze gaat maken. Deze keuze hangt af van een flink aantal verschillende factoren. Dit zijn grotendeels aspecten die niet direct kunnen worden aangepast door de Nederlandse contractspraktijk, maar die wij voor de volledigheid toch genoemd willen hebben. Dit betreft zaken zoals de kwaliteit van het Engels van de rechters, de flexibiliteit, snelheid en voortvarendheid van de procedure, de precieze inhoud van de NCC-regels en de kwaliteit van eventuele uitspraken die de NCC zal gaan doen. Het valt buiten de strekking van dit artikel om deze aspecten met verdere diepgang te bespreken.

Toch is er ook een belangrijk aantal ingrediënten voor succes van de NCC dat wel kan worden beïnvloed door de Nederlandse rechtspraktijk. Gedacht kan worden aan goede marketing, voorlichting en informatievoorziening. Het gaat hierbij om het creëren van naamsbekendheid van de NCC en het promoten van de keuze voor de NCC. Wij zullen dit hierna kort bespreken, maar voordat wij dat doen, willen wij ook opmerken dat bekendheid en populariteit vooral groeien door positieve ervaringen. Het is daarom van belang dat de NCC vanaf het begin investeert in bekendheid en vertrouwen in kwaliteit en dienstverlening. ${ }^{83}$ Het is zaak om te voorkomen dat er negatieve ervaringen ontstaan. Immers, als partijen van collega's horen dat ze negatieve ervaringen hebben gehad bij de NCC, kan dat funest zijn voor de opbouw van een succesvol NCC.

Om bij te dragen aan meer naamsbekendheid zal de rechtspraktijk de NCC moeten promoten en onder de aandacht moeten brengen. De mogelijkheid om te procederen bij de NCC zal actief verspreid moeten worden, zodat partijen zich bewust worden van deze optie. Dit betekent dat op zo veel mogelijk verschillende manieren moet worden getracht de NCC te promoten. Hierbij kan worden gedacht aan het schrijven van artikelen en het doen van onderzoek, maar ook advocaten en Nederlandse handelspartijen kunnen een grote rol spelen door de NCC actief te promoten, bijvoorbeeld door cliënten informatie te verstrekken over de NCC of zelf proactief te kiezen voor de NCC. Nadat internationale partijen zich op deze manier bewust zijn geworden van het bestaan van de NCC, is het zaak om te zorgen dat ze ook daadwerkelijk kiezen voor de NCC als forum voor

83. Bauw 2016, p. 97 geschillenbeslechting. Immers, alleen met voldoende klandizie en zaken zal de NCC een succes kunnen worden, en met louter naamsbekendheid komt de NCC er dus nog niet. Ook hier geldt weer dat de Nederlandse rechtspraktijk bij kan dragen door actief te promoten, door zelf te kiezen voor de NCC en door argumenten over te dragen aan internationale partners. Mensen laten zich immers leiden door wat de meeste, sociaal vergelijkbare, andere mensen doen en goedkeuren of afkeuren. ${ }^{84}$

\section{Opteren voor de NCC}

Het recente verleden laat een ontwikkeling zien van toenemende beslechting van internationale handelsgeschillen door middel van (internationale) arbitrage en door (buitenlandse) commercial courts. Als niets zou worden ondernomen, zou deze trend doorzetten. Bestaande kennis en ervaring van de Nederlandse rechtspraak en advocatuur met grote internationale handelszaken wordt dan steeds minder benut en zal daardoor (verder) afnemen. Aangezien deze beperkte kennis en ervaring voor Nederlandse ondernemingen en advocaten reden is om steeds vaker voor buitenlandse rechters of arbitrage te kiezen, heeft dit een zichzelf versterkend effect. ${ }^{85}$ Het initiatief om het tij te keren, nu het nog niet te laat is, verdient dan ook bijval. Dit geldt te meer daar het plan van Nederland tot het oprichten van een commercial court niet alleen staat, maar is voorafgegaan door (toevoegingen aan de langer bestaande opties in Londen en Delaware door) Dublin (2004), Dubai (2006) en Singapore (2015), en ongetwijfeld zal worden gevolgd door andere. Met de NCC zal de kwaliteit van de Nederlandse rechtspraak over Engelstalige internationale contracten en geschillen worden verhoogd. ${ }^{86}$ Dit zal bijdragen aan de waarde van de Nederlandse rechtspraak als exportproduct, alsook aan de ranking van Nederland op de zogeheten Rule of Law Index, die nu al bijzonder goed is. ${ }^{87}$

Dit effect van de sociale norm, oftewel van hoe het gaat in de praktijk, leert ook dat de nieuwe positieve mogelijkheden die de NCC te bieden heeft aan contractspartijen en aan de Nederlandse rechtspraktijk, op zich nog niet garant staan voor het succes van de NCC. Hiervoor

84. Zie R.B. Cialdini e.a., Managing social norms for persuasive impact, Social Influence 2006/1, p. 3-15; P.W. Schultz e.a., The constructive, destructive, and reconstructive power of social norms, Psychological Science 2007/18, p. 429-434.

85. Zie Raad voor de rechtspraak 2015, p. 5.

86. Aldus ook Drion 2017

87. Nederland staat thans op de vijfde plaats van de Rule of Law Index van 2016. De Index van het World Justice Project presenteert in eigen bewoordingen ' (...) a portrait of the rule of law in each country by providing scores and rankings organized around eights factors: constraint on government powers, absence of corruption, open government, fundamental rights, order and security, regulatory enforcement, civil justice, and criminal justice'. Op het gebied van civil justice staat de Nederlandse rechtspraak zelfs op nummer één van deze wereldranglijst. Zie Schelhaas 2017. 
is meer nodig, waaronder goede promotie en positieve ervaringen. Meegenomen is in ieder geval dat de NCC de juiste ingrediënten bevat om aantrekkelijk te zijn voor contractspartijen die een internationaal handelsgeschil in Nederland willen oplossen. Niet alleen is de keuze voor de locatie met de daaraan klevende voordelen een pluspunt van de NCC, ook de inhoudelijke aspecten zoals behandeling door een meervoudige kamer, moderne digitale faciliteiten, de voortvarendheid en de relatief lage kosten van een procedure zorgen dat de NCC een aantrekkelijk alternatief wordt ten opzichte van bijvoorbeeld het commercial court in Londen. Een keuze voor de NCC leidt voor betrokken partijen tot aanzienlijke kostenbesparingen. Wat nu rest om de NCC een succesvol alternatief te laten worden, is dat partijen er daadwerkelijk voor opteren om te gaan procederen bij de NCC. Het is aldus aan de rechtspraktijk. 